\title{
Hubungan status gizi dengan status anemia pada mahasiswa putri
}

\author{
Ariyani Lutfitasari* \\ Program Studi S1 Kebidanan, Universitas Muhammadiyah Semarang- Indonesia
}

\begin{abstract}
One of the nutritional problems experienced during adolescence is anemia. Anemia can have various effects on adolescents, including reducing body resistance so that they are prone to disease, decreased activity, and learning achievement due to lack of concentration. The purpose of this study was to determine the relationship between nutritional status and anemia status in students of the Kendal Regency Government Midwifery Academy, Central Java Province. This study used an analytic study design with a cross-sectional approach. The sample in this study were students who met the inclusion criteria, then calculated using the simple random sampling technique, the sample size was calculated using the Sovlin formula. The results were 52 respondents. The results of the chi-square statistical test showed the value of $\rho$ was 0.020 . The test got a value of $\rho<0.05$, which means that there is a significant relationship between nutritional status and anemia status in students of the Midwifery Academy of Kendal Regency.
\end{abstract}

Keywords: nutritional status; anemia status; BMI, adolescence

\begin{abstract}
Masalah gizi yang biasa dialami pada masa remaja salah satunya adalah anemia. Anemia dapat menimbulkan berbagai dampak pada remaja antara lain menurunkan daya tahan tubuh sehingga mudah terkena penyakit, menurunnya aktivitas dan prestasi belajar karena kurangnya konsentrasi. Tujuan penelitian ini yaitu untuk mengetahui hubungan antara status gizi dengan status anemia pada mahasiswa Akademi Kebidanan Pemerintah Kabupaten Kendal Provinsi Jawa Tengah. Penelitian ini menggunakan desain study analitik dengan pendekatan Cross Sectional. Sampel dalam penelitian ini adalah mahasiswa yang memenuhi kriteria inklusi, kemudian hitung menggunakan teknik simple random sampling, besar sampel dihitung menggunakan rumus Sovlin didapatkan hasil sebanyak 52 responden. Hasil uji statistik chi-square menunjukkan nilai $\rho$ adalah 0,020 . Uji tersebut mendapatkan nilai $\rho<0,05$ yang berarti bahwa terdapat hubungan bermakna antara status gizi dengan status anemia pada mahasiswa Akademi Kebidanan Pemerintah Kabupaten Kendal.
\end{abstract}

Kata Kunci: status gizi; status anemia; IMT; remaja putri

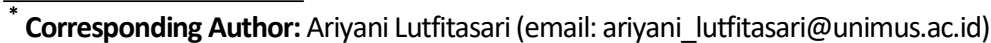




\section{Pendahuluan}

Masalah gizi merupakan masalah dalam daur perkembangan sepanjang usia. Gizi selama masa pertumbuhan merupakan salah satu faktor penentu kecerdasan. Gizi buruk, anemia, Gangguan Akibat Kurang lodium (GAKI), dan Kurang Vitamin A (KVA) masih merupakan kendala yang harus ditanggulangi di Indonesia. Gizi kurang pada umumnya di mulai dari dalam kandungan dan kemudian berlanjut, terutama bila janin perempuan ke dalam kehidupan remaja dan dewasa. Data Riskesdas tahun 2013 menyatakan prevalensi gizi buruk adalah 5,7 \%, gizi kurang 19,6\% , sangat kurus 5,3\% , kurus 6,8\% , dan gemuk 11,9\% (FKM UI, 2007; Irianto, 2014 dan Supariasa, 2016).

Data hasil Riskesdas tahun 2013 menyebutkan, prevalensi anemia di Indonesia yaitu $21,7 \%$ dengan penderita anemia berumur 5-14 tahun sebesar $26,4 \%$ dan $18,4 \%$ penderita berumur 15-24 tahun sedangkan prevalensi remaja kurus relative sama tahun 2007 dan 2013, dan prevalensi sangat kurus naik $0,4 \%$. Sebaliknya prevalensi gemuk naik dari 1,4\% (2003) menjadi 7.3\% di tahun 2013. Survey yang dilakukan oleh Gross et al di Jakarta dan Yogyakarta melaporkan prevalensi anemia pada remaja sebesar $21,2 \%$. Jumlah penduduk usia remaja (10-19 tahun) di Indonesia sebesar 26,2\% yang terdiri dari 50,9\% laki-laki dan 49,1\% perempuan (Riskesdas, 2013; Kemenkes RI, 2014).

Masalah gizi yang biasa dialami pada masa remaja salah satunya adalah anemia. Anemia adalah penurunan kuantitas sel-sel darah merah dalam sirkulasi atau jumlah hemoglobin berada dibawah batas normal. Gejala anemia yang sering dialami antara lain lesu, lemah, pusing, mata berkunang-kunang, dan wajah pucat. Anemia dapat menimbulkan berbagai dampak pada remaja antara lain menurunkan daya tahan tubuh sehingga mudah terkena penyakit, menurunnya aktivitas dan prestasi belajar karena kurangnya konsentrasi (Indartanti, 2014)

Menurut penelitian dari Permaisih, status gizi remaja dapat di tentukan melalui pemeriksaan laboratorium maupun secara antropometri. Kekurangan kadar Hemoglobin atau anemia dengan pemeriksaan darah. Antropometri merupakan cara penentuan status gizi yang paling mudah dan murah. Indeks Masa Tubuh (IMT) direkomendasikan sebagai indikator yang baik untuk menentukan status gizi remaja (Waryana, 2010). Penyebab prevalensi anemia yang tinggi pada wanita disebabkan banyak faktor antara lain konsumsi 
zat besi yang tidak cukup dan absorbsi zat besi yang rendah, pendarahan, penyakit malaria, infeksi cacing maupun infeksi lainnya dan remaja putri mengalami siklus menstruasi setiap bulan (Miller, et al 2009)

Faktor penyebab masalah gizi remaja diantaranya yaitu kebiasaan makan yang buruk berpangkal pada kebiasaan makan keluarga yang buruk sejak kecil, pemahaman gizi yang keliru pada remaja seperti membatasi makanan agar menjaga kelangsingan tubuh, kesukaan terhadap makanan tertentu seperti hanya makan junk food. Masalah gizi pada remaja akan berdampak negatif pada tingkat kesehatan masyarakat seperti penurunan konsentrasi belajar, penurunan kesegaran jasmani dan resiko melahirkan bayi BBLR (Waryana, 2010; Adriani, 2016).

Menurut Arumsari (2008), status gizi berkorelasi positif dengan konsentrasi hemoglobin, artinya semakin buruk status gizi seseorang maka semakin rendah kadar $\mathrm{Hb}$ didalam darah. Penelitian Permaesih (2005), menyatakan ada hubungan antara Indeks Massa Tubuh dengan anemia, remaja putri dengan Indeks Massa Tubuh kurus memiliki resiko 1,4 kali menderita anemia dibandingkan dengan remaja putri dengan IMT normal (Sumarmi, 2016).
Penelitian Wibowo, (2013) menyatakan bahwa dari hasil uji Chi-Square didapatkan nilai $p$-value $=0,000$ maka dapat disimpulkan bahwa ada hubungan yang bermakna antara status gizi dengan anemia. Hal ini disebabkan karena asupan gizi dalam tubuh kurang dan hal ini menyebabkan kebutuhan gizi dalam tubuh tidak terpenuhi terutama kebutuhan gizi seperti zat besi yang merupakan salah satu komponen terpenting dalam pembentukan hemoglobin akan menyebabkan berkurangnya bahan pembentuk sel darah merah, sehingga sel darah merah tidak dapat melakukan fungsinya dalam mensuplai oksigen yang akan mengakibatkan anemia.

$$
\text { Penelitian dari Bagni,et al (2013) }
$$
menyebutkan bahwa remaja perempuan yang kelebihan berat badan menunjukkan tingkat Hemoglobin yang lebih rendah daripada mereka yang tidak kelebihan berat badan $(12,2$ $\mathrm{gr} / \mathrm{dL}$ vs $12,8 \mathrm{gr} / \mathrm{dL}, \mathrm{p}<0,01)$. Kadar Hb yang kurang menunjukkan kelebihan berat badan sebagai faktor risiko terjadinya defisiensi besi di kalangan remaja. Penelitian dari Cepeda-lopez et al., (2011) berdasarkan hasil analisis regresi linier, obesitas merupakan prediktor independen yang signifikan dari anemia defisiensi besi dengan rasio odds 1,92 (95\% Cl: $1,23,3,01)$. 
Hasil studi pendahuluan peneliti simple random sampling, besar sampel mengambil sampel untuk studi pendahuluan dihitung menggunakan rumus Sovlin sebanyak 10 orang mahasiswa, kemudian didapatkan hasil sebanyak 52 responden. diukur indeks massa tubuh dan kadar hemoglobin, didapatkan data sebagai berikut : 1 orang mahasiswa dengan status gizi normal, mengalami anemia, 5 mahasiswa berstatus gizi normal tidak mengalami anemia. 2 orang mahasiwa dengan status gizi obesitas, mengalami anemia dan 2 orang mahasiswa dengan obesitas tidak mengalami anemi . Berdasarkan permasalahan tersebut maka penulis tertarik untuk meneliti Hubungan Status Gizi Dengan Status Anemia Pada Mahasiswa Putri

Tujuan penelitian ini yaitu untuk mengetahui hubungan antara status gizi dengan status anemia pada mahasiswa Akademi Kebidanan Pemerintah Kabupaten Kendal Provinsi Jawa Tengah

\section{Metode}

Penelitian ini menggunakan desain study analitik dengan pendekatan Cross Sectional. Populasi dalam penelitian ini adalah mahasiswa Akademi Kebidanan Pemerintah Kabupaten Kendal Provinsi Jawa Tengah yang berjumlah 90 orang. Sampel dalam penelitian ini adalah mahasiswa yang memenuhi kriteria inklusi, kemudian hitung menggunakan teknik Responden yang memenuhi kriteria penelitian adalah mahasiswa dengan usia menarche 1015 tahun, tidak sedang menstruasi saat dilakukan penelitian dan mahasiswa yang tidak mengalami perdarahan yang banyak baik dari luka maupun penyebab lainnya.

Pengukuran status gizi yaitu dengan metode antropometri indeks massa tubuh (IMT) pengukurannya menggunakan timbangan injak ( sudah lulus uji kalibrasi) dan mikrotoa, dengan kriteria Berat badan kurus, IMT < 18,5, Normal 18,5-25, gemuk > 25,1. Kadar Hemoglobin dengan pemeriksaan laboratorium dengan metode hemoanalyzer merk Celtac, Tipe MEK-5208 buatan Nihon Kohden. Dikategorikan tidak anemia apabila kadar hemoglobin $\geq 12$ gr\%, anemia $<12$ gr\% (Kemenkes RI, 2016).

Pengambilan data sampel dalam penelitian ini dilakukan mulai pada tanggal 11 September 2017. Dilakukan pemilihan sampel dengan mengacu pada kriteria inklusi dan kriteria eksklusi pada setiap kelas. Setelah itu dilakukan pengundian dan setiap kelas di ambil 17-18 responden sampai jumlah sampel terpenuhi yaitu 52 responden. Dalam penelitian ini tidak 
ada responden yang drop out. Kemudian peneliti meminta kesediaan responden untuk ikut serta dalam penelitian ini dengan menandatangi lembar informed concent.

\section{Hasil dan Pembahasan}

Responden dalam penelitian ini adalah Mahasiswa semester $\mathrm{V}$ Akademi Kebidanan Pemerintah Kabupaten Kendal sejumlah 52 orang. Semua berjenis kelamin perempuan dan yang memenuhi kriteria inklusi dan eksklusi sebagai subjek penelitian sejumlah 52 orang. Hasil analisis untuk distribusi frekuensi karakteristik responden dan variabel penelitian secara ringkas disajikan pada Tabel 1.

Tabel 1 menunjukkan bahwa pendidikan ayah mahasiswa Akademi Kebidanan Pemerintah Kabupaten Kendal di kategorikan menjadi dua yaitu rendah dan tinggi. Sebanyak $22(42,3 \%)$ ayah berpendidikan rendah dan sebanyak $30(57,7 \%)$ berpendidikan tinggi. Pendidikan terendah adalah tidak bersekolah dan pendidikan yang paling tinggi adalah S1 (Sarjana). Pendidikan ibu mahasiswa Akademi Kebidanan Pemerintah Kabupaten Kendal yaitu Sebanyak 27 (51,9\%) berpendidikan rendah dan sebanyak 25 (48,1\%) berpendidikan tinggi. Pendidikan terendah Ibu adalah tidak bersekolah dan pendidikan yang paling tinggi ada- lah S1 (Sarjana).

Pendapatan orang tua mahasiswa Akademi Kebidanan Pemerintah Kabupaten Kendal di kategorikan menjadi tiga yaitu rendah $(<\mathrm{Rp}$. 3.500.000), sedang (Rp. 3.500 .000 7.500.000), tinggi (> Rp. 7.500.000,00) (Eryanto, 2013). berpenghasilan sedang sebanyak $17(19,2 \%)$ dan sisa nya berpenghasilan tinggi sebanyak 10 (19,2\%). Penghasilan terendah orang tua adalah Rp. 1.000.000,00 dan penghasilan yang paling tinggi Rp. 10.000.000,00.

Tabel 2 menunjukkan bahwa status gizi responden yang masuk dalam kategori berat badan kurus sejumlah 15 responden (28,8\%), normal sejumlah 28 responden $(53,8 \%)$, Gemuk 9 responden (17,3\%) dengan IMT terendah 16,60 dan yang tertinggi 33,20.

Tabel 3 menunjukkan status anemia responden mengalami anemia sejumlah 26 responden (50 \%) dan yang tidak anemia sejumlah 26 responden (50\%) dengan kadar hemoglobin terendah adalah $10 \mathrm{gr} \%$ dan yang tertinggi adalah $14,4 \mathrm{gr} \%$.

Menurut Arisman dalam penelitian yang dilakukan oleh Sumarmi, 2016, remaja putri membutuhkan zat besi paling banyak yang digunakan untuk mengganti zat besi yang terbuang bersama darah haid, disamping keper- 
luan untuk menopang pertumbuhan serta pematangan seksual. Status gizi remaja putri merupakan kunci keberhasilan kelangsungan hidup mereka dan anak-anak yang dilahirkan pada masa depan karena keadaan kesehatan, gizi dan mental berpengaruh terhadap keadaan kehamilan.

Tabel 1. Hasil Distribusi Frekuensi Karakteristik Responden Berdasarkan Pendidikan Orang Tua dan Pendapatan Orang Tua Mahasiswa Akademi Kebidanan Pemerintah Kabupaten Kendal

\begin{tabular}{lll}
\hline Karakteristik Responden & Jumlah & Persen (\%) \\
\hline Pendidikan Formal Ayah & & \\
Rendah (SD-SMP) & 22 & $42,3 \%$ \\
Tinggi (SMA-Sarjana) & 30 & $57,7 \%$ \\
Pendidikan Formal Ibu & & \\
Rendah (SD-SMP) & 27 & $51,9 \%$ \\
Tinggi (SMA-Sarjana) & 25 & $48,1 \%$ \\
Pendapatan Orang Tua & & \\
Rendah (<3,5 juta) & 25 & $48,1 \%$ \\
Sedang (3,5 -7,5 juta) & 17 & $32,7 \%$ \\
Tinggi (>7,5 juta) & 10 & $19,2 \%$ \\
Menarche umur 10-12 tahun & 27 & $51,9 \%$ \\
Menarche umur 13-15 tahun & 25 & $48,1 \%$ \\
\hline Jumlah & 52 & $100 \%$ \\
\hline
\end{tabular}

Tabel 2. Distribusi Frekuensi Status Gizi Mahasiswa Akademi Kebidanan Pemerintah Kabupaten Kendal

\begin{tabular}{lcc}
\hline Status Gizi & Jumlah & Persen (\%) \\
\hline Kurus & 15 & $28,8 \%$ \\
Normal & 28 & $53,8 \%$ \\
Gemuk & 9 & $17,3 \%$ \\
Jumlah & 52 & $100 \%$ \\
\hline
\end{tabular}

Tabel 3. Distribusi Frekuensi Status Anemia Mahasiswa Akademi Kebidanan Pemerintah Kabupaten Kendal

\begin{tabular}{lcc}
\hline Kadar Hemoglobin & Jumlah & Persen (\%) \\
\hline Anemia & 26 & $50 \%$ \\
Tidak Anemia & 26 & $50 \%$ \\
Jumlah & 52 & $100 \%$ \\
\hline
\end{tabular}

Tabel 4. Hubungan Status Gizi dengan Status Anemia Mahasiswa Akademi Kebidanan Pemerintah Kabupaten Kendal

\begin{tabular}{lccccccc}
\hline \multirow{2}{*}{ Status Gizi } & \multicolumn{9}{c}{ Status Anemia } & & \multirow{2}{*}{ Total } & $\%$ & P Value \\
\cline { 2 - 5 } & Anemia & $\%$ & Tidak anemia & $\%$ & & & \\
\hline Kurus & 11 & 21,2 & 4 & 7,7 & 15 & 28,8 & \\
Normal & 9 & 17,3 & 19 & 36,5 & 28 & 53,8 & 0,020 \\
Gemuk & 6 & 11,5 & 3 & 5,8 & 9 & 17,3 & \\
Jumlah & 24 & 46,2 & 28 & 53,8 & 52 & 100 & \\
\hline
\end{tabular}


Pada Tabel 4 dapat dilihat bahwa remaja putri dengan status gizi kurus yang menderita anemia, yaitu sejumlah 11 mahasiswa (21,2\%). Persentasenya lebih besar bila dibandingkan dengan responden dengan status gizi normal dan gemuk yang menderita anemia, yaitu sebanyak 9 mahasiswa (17,3\%) dan 6 mahasiswa (11,5\%).

Hasil uji statistik chi-square menunjukkan nilai $\rho$ adalah 0,020 . Uji tersebut mendapatkan nilai $\rho<0,05$ yang berarti bahwa terdapat hubungan bermakna antara status gizi dengan status anemia pada mahasiswa Akademi Kebidanan Pemerintah Kabupaten Kendal.

Indeks massa tubuh kurang dari 18,5 umum digunakan sebagai ukuran praktis dari kekurangan energi kronis pada individu atau populasi. Kekurangan Energi Kronis (KEK) disebabkan oleh asupan energi yang tidak mencukupi disertai dengan tingginya tingkat aktivitas fisik dan infeksi. Kekurangan Energi Kronik (KEK) telah dikaitkan dengan penurunan kapasitas kerja, mengurangi kinerja dan produktivitas (Bisai \& Bose, 2009).

Penelitian ini sependapat dengan penelitian dari Bagni,et al (2013) menyebutkan bahwa remaja perempuan yang kelebihan berat badan menunjukkan tingkat Hemoglobin yang lebih rendah daripada mereka yang tidak kelebihan berat badan $(12,2 \mathrm{gr} / \mathrm{dL}$ vs 12,8 $\mathrm{gr} / \mathrm{dL}, \mathrm{p}<0,01)$. Kadar $\mathrm{Hb}$ yang kurang menunjukkan kelebihan berat badan sebagai faktor risiko terjadinya defisiensi besi di kalangan remaja. Penelitian dari Cepeda-lopez et al., (2011) berdasarkan hasil analisis regresi linier, obesitas merupakan prediktor independen yang signifikan dari anemia defisiensi besi dengan rasio odds 1,92 (95\% Cl: 1,23, 3,01).

Penelitian dari Nead, et al (2019) hasil penelitian menunjukkan bahwa pada remaja terjadi defisiensi besi tertinggi yang sama-sama meningkat ketika status berat badan meningkat $(3,5 \%, 7,2 \%$, dan $9,1 \%, P<0,04)$. Remaja yang kelebihan berat badan ditemukan secara signifikan lebih kekurangan zat besi daripada mereka yang memiliki berat badan normal $(P=$ 0,05). Penelitian ini juga sependapat dengan penelitian yang dilakukan oleh Shara, et al (2017) menyebutkan bahwa Hasil uji statistik chi-square menunjukkan nilai $\mathrm{p}$ adalah 0,008, nilai OR adalah 0,089. Uji tersebut mendapatkan nilai $p<0,05$ yang berarti bahwa terdapat hubungan bermakna antara status gizi dengan kejadian anemia pada remaja putri di SMAN 2 Sawahlunto.

Namun penelitian ini tidak sependapat dengan penelitian dari Sumarmi (2016) yang menyebutkan bahwa berdasarkan hasil uji 
statistik dengan menggunakan uji chi-Square diperoleh hasil bahwa Ho lebih besar dari $\alpha=$ $5 \%(p=0,44)$, sehingga menunjukkan bahwa tidak ada hubungan antar status gizi dengan status anemia pada santriwati.

Penjelasan untuk hubungan kelebihan berat badan dengan penurunan status zat besi yaitu peningkatan aktivitas inflamasi pada jaringan adiposa individu yang mengalami obesitas, yang akan mengarah pada produksi hepcidin yang lebih tinggi, hormon utama untuk pengaturan penyerapan usus dan homeostasis besi. Sitokin inflamasi, terutama interleukin 6 , bertindak langsung di hepatosit, merangsang ekspresi hormon yang ketika bersentuhan dengan aliran darah, berikatan dengan ferroportin seluler, sebuah protein transmembran pengekspor zat besi. Ikatan ini menginduksi internalisasi ferroportin dan degradasi oleh lisosom, dengan hilangnya transporter ini, ekspor besi diblokir dan zat besi yang terdegradasi dipertahankan dalam sel makrofag, mendukung pengurangan sirkulasi zat besi. Dalam enterosit, internalisasi dan degradasi ferroportin menghambat transfer zat besi dari sitoplasma ke transferin plasma dan retensi zat besi tersebut menghambat penyerapan apikal dan pemanfaatan zat besi oleh sel-sel usus, semakin meningkatkan efek pada konsentrasi mineral yang beredar. Jadi, bahkan ketika asupan zat besi memadai, individu yang kelebihan berat badan dan dengan lemak tubuh yang berlebihan memiliki kecenderungan lebih tinggi untuk mengembangkan anemia defisiensi besi, karena ada pemanfaatan mineral yang lebih rendah dalam tubuh (Bagni,et al., 2013). Hasil penelitian dari Putri, et al (2010) dengan menggunakan analisis chi kuadrat yang menunjukkan bahwa hasil perhitungan $\chi 2$ hitung adalah $3,882<5,591$ dan nilai probabilitas adalah $0,144>0,05$ sehingga $\mathrm{H}$ diterima sehingga tidak ada hubungan antara status gizi berdasarkan Indeks masa Tubuh (IMT) dengan kejadian anemia pada remaja putri. Simpulan yang diperoleh yaitu tidak ada hubungan yang signifikan antara status gizi berdasarkan Indeks Massa Tubuh (IMT) dengan kejadian anemia pada remaja putri di STIKes Mitra Husada Karanganyar.

\section{Kesimpulan}

Hasil uji statistik chi-square menunjukkan nilai $\rho$ adalah 0,020 . Uji tersebut mendapatkan nilai $\rho<0,05$ yang berarti bahwa terdapat hubungan bermakna antara status gizi dengan status anemia pada mahasiswa Akademi Kebidanan Pemerintah Kabupaten Kendal. 


\section{Daftar Pustaka}

Bisai, S., \& Bose, K. (2009). Undernutrition in the Kora Mudi tribal population, West Bengal, India: A comparison of body mass index and mid-upper-arm circumference. Food and Nutrition Bulletin, 30(1), 63-67.

Cahya Daris Tri Wibowo, dkk. (2013). Hubungan Antara Status Gizi dengan Anemia pada Remaja Putri di Sekolah Menengah Pertama Muhammadiyah 3 Semarang Relationship Between Nutritional Status With Anemia in Young Women in Junior High School of Muhammadiyah 3 Semarang. Jurnal Kedokteran Muhammadiyah, 1, 3-7.

Cepeda-lopez, A. C., Osendarp, S. J. M., Melseboonstra, A., Aeberli, I., Gonzalez-salazar, F., Feskens, E., ... Zimmermann, M. B. (2011). Sharply higher rates of iron deficiency in obese Mexican women and children are predicted by obesity-related inflammation rather than by differences in dietary iron intake $1-3$, (Id).

Dea Indartanti, A. K. (2014). Hubungan Status Gizi dengan Kejadian Anemia Pada Remaja Putrl. Journal of Nutrition College, 3, 33-39.

Eryanto, H. (2013). Pengaruh Modal Budaya, Tingkat Pendidikan Orang Tua Dan Tingkat Pendapatan Orang Tua Terhadap Prestasi Akademik Pada Mahasiswa Fakultas Ekonomi Universitas Negeri Jakarta, 1(1), 39-61.

FKMUI, D. G. dan K. M. (2007). Gizi dan Kesehatan Masyarakat. Jakarta: Raja Grafindo Persada.

Heather A Eicher-Miller, et al. (2009). Food insecurity is associated with iron deficiency anemia in US. The American
Journal of Clinical Nutrition, 1358-1371.

I Dewa Nyoman Supariasa, dkk. (2016). Penilaian Status gizi. Jakarta: EGC.

Irianto, K. (2014). Gizi Seimbang dalam Kesehatan Reproduksi. Bandung: ALFABETA.

Kemenkes RI. (2014). Profil Kesehatan Indonesia Tahun 2013. Jakarta: Kementerian Kesehatan RI. https://doi.org/351.770.212 Ind P

Kemenkes RI. (2016). Pedoman Pencegahan dan Penanggulangan Anemia pada Remaja Putri dan WUS. Jakarta (ID): Kementerian Kesehatan RI.

Latifah, L. (2008). Gaki, anemia, kecerdasan, dan prestasi belajar anak remaja. Universitas Gajah Mada (Tesis Tidak Di Publiksasikan).

Merryana Adriani. (2016). Peranan Gizi dalam Siklus Kehidupan. Jakarta: Kencana.

N. Kadek Sri Eka Putri, et al. (2010). Hubungan Status Gizi Berdasarkan Indeks Massa Tubuh ( IMT ) Dengan Kejadian Anemia Pada Remaja Putri Di Stikes Mitra Husada Karang Anyar.

Nead, K. G. et al. (2019). Overweight Children and Adolescents: A Risk Group for Iron Deficiency. Pediatrics, 114(1).

Riskesdas. (2013). Riset Kesehatan Dasar (RISKESDAS) 2013. Laporan Nasional 2013, 1-384.

Shara, F. El, Wahid, I., \& Semiarti, R. (2017). Artikel Penelitian Hubungan Status Gizi dengan Kejadian Anemia pada Remaja Putri di SMAN 2 Sawahlunto Tahun 2014, 6(1), 202-207. 
Sumarmi, S. (2016). Hubungan Status Gizi Dengan Kejadian Darul Ulum Peterongan Jombang, 1(1).

Ursula Viana Bagni, et al. (2013). Overweight is associated with low hemoglobin levels in adolescent girls. Obesity Research \& Clinical Practice, 7(3), e218-e229.

Waryana. (2010). Gizi Reproduksi. Yogyakarta: Pustaka Rihama. 